\title{
Decomposing Interest Differentials: An International Borrowing and Lending Approach
}

\author{
Anthony J. Makin \\ University of Queensland
}

\begin{abstract}
This paper proposes a new economy-wide framework for decomposing international interest differentials based on aggregate borrowing and lending behaviour in economies whose domestic capital markets are highly globally integrated. Using macroeconomic rather than microeconomic concepts, this alternative approach demonstrates how key inter-relationships involving relative inflation levels and exchange rate expectations govern "average" domestic and foreign interest differentials. It also contributes by identifying different kinds of risk premia that arise due to economy-wide factors such as the level of foreign debt and country and political factors. Unlike standard interest parity approaches, based simply on arbitrage of financial asset returns, it shows that changing exchange rate expectations influence international interest differentials through both excess domestic borrowing and foreign lending behaviour.
\end{abstract}

- JEL Classifications: F15, F30, F34

- Key words: Interest parity, Loanable funds, Risk

\section{Introduction}

The existing international finance literature is dominated by empirical studies that test the key theorems of exchange rate and interest rate behavior, such as purchasing power parity, uncovered interest rate parity and the Fisher interest rate

\footnotetext{
*Corresponding address: Professor Anthony J. Makin, School of Economics, University of Queensland, Brisbane Qld 4072, Australia. E-mail: makin@economics.uq.edu.au (C2004-Center for International Economics, Sejong Institution, All Rights Reserved.
} 
effect. ${ }^{1}$ Previous theoretical and empirical analysis of cross border interest differentials has been based on the principles of arbitrage and investment decision making by optimizing investors. Standard relationships are invariably derived with reference to arbitrage of returns on alternative assets issued in different currencies, with equilibrium characterized in stock terms. Meanwhile, econometric studies of interest parity, uncovered and real, and of risk premia, test for the correspondence of rates of return on specific domestic and foreign securities with an equivalent term to maturity. ${ }^{2}$ Since this entire field of study is micro-based, by definition it abstracts from economy-wide influences, such as the international flow of funds and stock of a country's foreign debt.

Loanable funds analysis suggests that the "average" interest rate in a closed economy reflects the supply and demand for funds arising from saving and investment behaviour. ${ }^{3}$ However, international integration of financial markets has greatly increased the scale of external borrowing and lending with implications for interest differentials interpreted as international macroeconomic phenomena. ${ }^{4}$ In financially liberalised open economies, aggregate borrowing for investment spending can exceed domestic saving to the extent of foreign borrowing, or domestic saving exceed investment to the extent of foreign lending. Such has been the recent experience of many economies that have recorded sizeable external account imbalances.

At the same time, the standard macroeconomic approach to interpreting the relationship between domestic and foreign interest rates, capital flows and exchange rates is the Mundell (1963) and Fleming (1962) model in which domestic interest rates are immediately determined by the stock interaction between money demand and supply. Yet, this model fails to relate international capital flows directly to the domestic supply and demand for loanable funds, nor

\footnotetext{
The standard precepts of interest rate theory are exposited in Fisher (1930), Roll (1970) and Roll and Solnik (1979). Arbitrage based interpretations of uncovered interest parity are proposed by Aliber (1973), Isard (1992) and Taylor (1995), amongst others.

${ }^{2}$ Empirical studies of uncovered and real interest parity include Cumby (1988), Cumby and Mishkin(1986), Dutton (1993), Fujihara and Mougoue (1996), Kneeshaw and Van den Bergh (1985), Lewis (1995), Mark (1985) and Mishkin (1984).
}

${ }^{3}$ See for instance, Tsiang (1989) and Van Horne (2000).

${ }^{4}$ Fukao (1993), Lewis (1995), Marston (1995), Meerschwam (1991) and Throop (1994) examine interest rate aspects of international capital market integration. 
recognise that domestic investment and saving must diverge whenever there is net international borrowing and lending.

The aim of this paper is to outline a new macroeconomic framework for interpreting the linkages between domestic saving and investment, international borrowing and lending, interest rates, inflation, risk, and exchange rate expectations for a small open economy. By reconciling the international flow of funds with the standard parity relationships, it provides a new means of identifying the factors that contribute to international interest differentials and cause deviations from uncovered interest parity as a macroeconomic phenomenon. After introducing the main international macroeconomic relationships governing observed interest rates and the flow of funds, section 2 shows how borrowing and lending behaviour under inflationary conditions gives rise to the Fisher open relationship. Section 3 introduces different forms of time varying risk, including credit risk and country risk to reveal how interest risk premia arise. Section 4 then shows how changing exchange rate expectations also influence international borrowing and lending behaviour and hence cross border interest differentials.

\section{The Fisher Effect and Uncovered Interest Parity}

The following economy-wide accounting and behavioral relationships lay the foundations for linking the nominal interest rate of a small open economy to the world interest rate via aggregate international financial flows, inflation rates and exchange rate expectations.

$$
\begin{aligned}
& i_{r}=\dot{i}_{r}^{*} \\
& i^{*}=i_{r}^{*}+\pi^{*} \\
& i=i_{r}+\pi \\
& \bar{Y}-C(i)=S(i)=L(i) \quad ; \quad S_{i}>0, L_{i}>0 \\
& I=I(i, \beta)=B(i, \beta) \quad ; \quad I_{i}<0, I_{\beta}>0 \\
& B(i)-L(i)=C A B=B^{*}\left(i, i^{*}\right) \quad ; \quad B_{i}^{*}<0, B_{i^{*}}^{*}<0 \\
& \hat{E}=\frac{\left(e_{t+1}-e_{t}\right)}{e_{t}}
\end{aligned}
$$




$$
\begin{gathered}
\pi-\pi^{*}=\Delta \pi=\hat{E} \\
B^{*}\left(i, i^{*}, \beta, \pi^{*}, \Delta \pi\right)=L^{*}\left(i, i^{*}, \pi^{*}, \hat{E}\right)
\end{gathered}
$$

where

$i_{r}$ is the real domestic interest rate

$i_{r}^{*}$ is the exogenous real world interest rate

$i^{*}$ is the nominal world interest rate

$i$ is the nominal domestic interest rate

$\pi$ is expected domestic inflation

$\pi^{*}$ is expected world inflation

$\bar{Y}$ is the small economy's given national income

$C$ is its domestic consumption expenditure

$S$ is domestic saving

$L$ is domestic lending

$I$ is real domestic investment

$\beta$ is real domestic investment opportunities

$C A B$ is the current account balance

$B$ is the domestic demand for funds

$B^{*}$ is the external borrowing requirement

$\hat{E}$ is expected currency depreciation

${ }^{e} t+1$ and $e_{t}$ are spot exchange rates at times $t+1$ and $t$

$\Delta \pi$ is domestic inflation in excess of world inflation, and

$L^{*}$ is foreign lending.

Consistent with the small country assumption and with a key premise of intertemporal open economy models, domestic borrowers face a domestic real interest rate, $i_{r}$, set equal to the exogenous world interest rate, $\dot{i}_{r}^{*}$, in initial equilibrium as specified in equation (1). In addition, however, nominal domestic and world interest rates will reflect expectations of respective domestic and world inflation rates, according to the Fisher interest rate equations (2) and (3).

Domestic lending is assumed to be positively related to the domestic interest rate and borrowing negatively related, as specified by equations (4) and (5). Saving, the residual between income and consumption, is lent by exchanging funds for interest earning financial instruments, such as bonds or certificates of deposit, which are issued by domestic borrowers to fund real investment spending. 
In a small open economy, facing a given world interest rate, an excess demand for funds by domestic residents creates an ex ante current account imbalance and an external borrowing requirement (equation (6)).

These relationships can now be graphically represented for a small open economy in loanable funds - interest rate space, as shown in Figure 1. The left panel of Figure 1 shows the supply and demand for funds for a range of interest rates. The upward sloping schedule, $L_{0}$, in Figure 1 can be interpreted as a demand for interest earning assets schedule by domestic savers. The higher the domestic interest rate for a given level of wealth, the higher is the demand for interest earning assets, relative to the demand for other financial and real assets, such as equities and real estate. Domestic borrowers supply the interest earning financial investments on the other side of the market for loanable funds. They issue more instruments the lower the interest rate is, as conveyed by the downward sloping $B_{0}$ schedule. Total borrowing can exceed domestic lending at the world interest rate to the extent of foreign borrowing. The lower is the world interest rate, the greater is domestic residents' net demand for foreign funds, as shown by the downward sloping $B_{0}^{*}$ schedule in the right side panel of Figure 1.

A rise in the economy's borrowing requirement, due for instance to increased real investment opportunities (a rise in $\beta$ ) shifts the $B_{0}$ schedule rightward to $B_{1}$, giving rise to an ex ante external borrowing requirement of $O f$ as shown in the right panel of Figure 1. To obtain foreign funds, additional debt instruments are issued by resident borrowers and are denominated in the domestic currency. If

Figure 1. Interest Parity and the International Flow of Funds

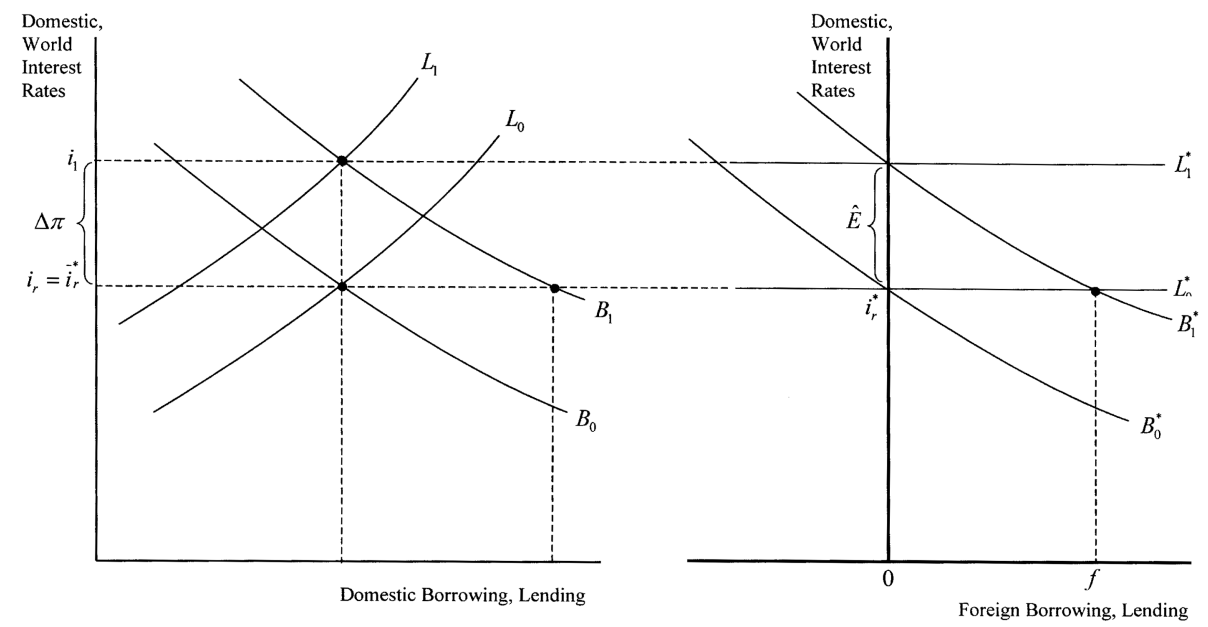


international capital mobility is perfect in the textbook sense, then foreign lenders fully meet the funding requirement purchasing the extra bonds on issue, that is by lending $O f$ at $i_{r}^{*}$, the going world interest rate. Under these conditions, ex ante foreign lending behaviour is shown by the horizontal $L_{0}^{*}$ schedule.

Now consider the behaviour of interest rates and the international flow of funds after the onset of higher inflation in the small borrowing economy. The rise in domestic inflation exceeds the world inflation rate (assumed for the sake of exposition to be zero) by $\Delta \pi$. The domestic borrowing and lending are depicted in the first instance by the $B_{0}$ and $L_{0}$ schedules. Once higher domestic inflation begins however, saver-lenders would insist on being paid a higher nominal rate of return to compensate for the erosion in the value of their principal.

Meanwhile, the domestic demand for loanable funds rises from $B_{0}$ to $B_{1}$ (which for expositional purposes we assume is the same sized shift as for the above case of a rise in real investment opportunities). This increased demand for funds arises because borrowers also realise that it is possible to repay less capital in real terms during an inflationary period. As a result, the domestic nominal interest rate rises from $i_{r}$ to $i_{1}$ consistent with the Fisher interest rate effect, expressed in equation (3) above. It also causes the external borrowing schedule to shift up to $B_{0}^{*}$. The relationship between the domestic interest rate and inflation differential is depicted on the vertical axis of the left side panel of Figure 1.

Questions then arise about the behaviour of foreign lenders under these circumstances. This is where the relative purchasing power parity relation comes in (equation (8)). If domestic inflation is expected to exceed global inflation, then foreign lenders should also anticipate the exchange rate of the borrowing economy to depreciate, as predicted by the expected form of relative purchasing power parity. ${ }^{5}$ Hence, foreign lenders would require a higher rate of return to compensate them for the capital losses incurred on maturity of those bonds.

The lending schedule would shift up by the extent of the shift in the borrowing schedule due to domestic inflation. In equilibrium, the demand for foreign funds equals the supply of foreign funds forthcoming, as expressed in equation (9) above. The result is that the domestic interest rate then differs from the foreign interest rate in accordance with the Fisher open, or uncovered interest rate relationship. That is,

\footnotetext{
${ }^{5}$ Surveys of the theory and evidence for purchasing power parity include Dornbusch (1992), Isard (1995) and Rogoff (1996).
} 


$$
i=i_{r}^{*}+\Delta \pi=i^{*}+\hat{E}
$$

\section{Foreign Borrowing, Lending and Risk}

In the above analysis, foreign lenders lend freely without being impeded by official restrictions such as exchange controls. Yet, even without exchange controls, risk-averse foreign investors can be unwilling to fully fund the borrowing requirements of domestic residents. Risk can now be introduced to the above analysis through the following equations.

$$
\begin{gathered}
F_{t}=\int_{0}^{t} B^{*}(t) \cdot d t \\
\rho=\rho\left(F_{t}, R\right) ; \quad \rho_{F_{t}}>0, \rho_{R}>0
\end{gathered}
$$

Equation (11) expresses the stock-flow relation between external borrowing and foreign debt levels where $F_{t}$ is the stock of foreign debt at time $t$, while equation (12) implies that foreign lenders demand a premium, $\rho$, to compensate for rising foreign debt levels and other forms of risk, such as political and country risk, summarized by term $R$. Hence, the foreign lending schedule slopes upward, as shown by schedule $L_{2}^{*}$ in Figure 2.

Figure 2. Foreign Borrowing, Lending, Interest Rates and Creditworthiness

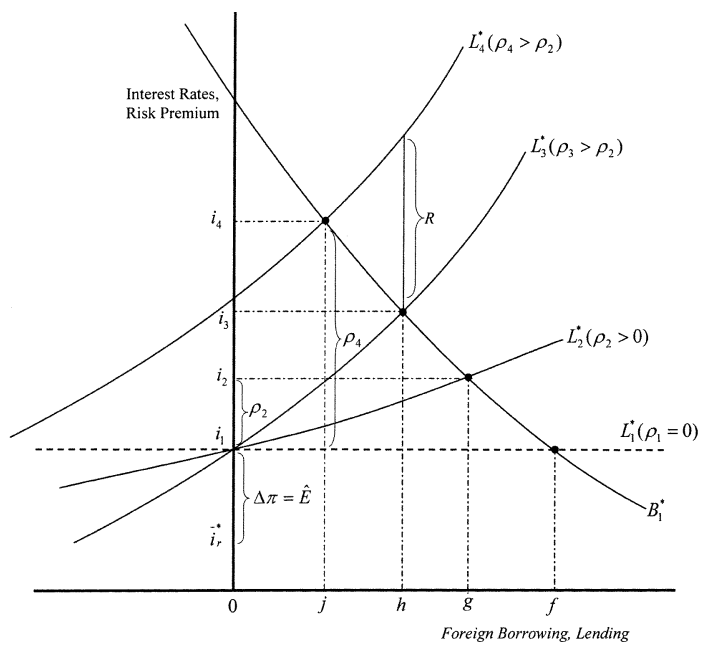


The more risk averse foreign investors are to rising foreign debt, the steeper the slope of the $L^{*}$ schedule and the higher the risk premium will be. Under these circumstances, international capital is imperfectly mobile. In addition, foreign lenders are unlikely to perceive debt instruments issued by the borrowing country as perfect substitutes for debt instruments issued in their home economies. For instance, even if such instruments were ostensibly the same in terms of their maturity structure, foreign lenders may be uncertain about political stability, holding assets in currencies that are perceived to be more risky, the future tax treatment of their earnings or about capital controls being reimposed. Such factors are captured in the $R$ term of equation (12).

Figure 2 shows for a given ex ante external borrowing requirement of $O f$, foreign funds to this amount will only be loaned in the limiting case of standard uncovered interest parity, that is, when $i_{r}=i_{r}^{*}+\hat{E}$. However, to the extent that foreigners react negatively to rising foreign debt levels as reflected in the $L_{2}$ schedule, then the amount actually lent will be $O g$. With this lesser amount of lending and capital inflow, the domestic interest rate of the borrowing country will be higher at $i_{2}$ which now differs from the foreign interest rate to the extent of expected depreciation and the debt related risk premium, $\rho_{2}$, as indicated on the vertical axis. That is, in general

$$
i_{r}=i_{r}^{*}+\hat{E}+\rho
$$

The more averse foreign lenders are to the rising external debt levels of borrower nations, the higher the equilibrium domestic interest rate, as shown by the foreign lending schedule $L_{3}^{*}$ reflecting $\rho_{3}>\rho_{2}$. For instance, the slope of the foreign lending schedule is likely to steepen following a downgrading in creditworthiness by international rating agencies. For instance, under these circumstances, ex post borrowing and lending would be $O h$ and the domestic interest rate $i_{3}$. Yet $\rho$ also captures risk factors not directly related to the foreign indebtedness level such as overall country risk due for instance to political instability, through the shift variable $R$. If the debtor economy experienced a political crisis for instance, foreign investors would suddenly become less willing to lend, causing the $L_{3}^{*}$ schedule to rise to $L_{4}^{*}$. The cross border interest differential would be higher at $\left(i_{4}-i_{r}^{*}\right)$ and only $O j$ lending would have occurred ex post. 


\section{Foreign Borrowing, Lending and Exchange Rate Expectations}

Exchange rate expectations have so far played a role through the purchasing power parity relationship, as it affects the lending decisions of foreigners when higher domestic inflation is expected. Yet, domestic borrowers and foreign lenders may expect the exchange rate to depreciate by even more than this, for reasons other than a rise in domestic inflation over world inflation. These reasons could include the behaviour of the borrowing economy's terms of trade, the sustainability of its trade imbalance, or a change in the type of exchange rate regime adopted by the home economy.

It is now possible to incorporate the effects of changing exchange rate expectations for such reasons into this framework, as shown in Figure 3. Here, in the foreign debt averse case the domestic interest rate, $i_{1}$, initially exceeds the world rate, $i_{r}{ }^{*}$, by the expected higher domestic inflation and the risk premium. However, foreign lenders now suddenly expect the exchange rate to depreciate by even more than the inflation differential, that is, by $\Delta \hat{E}$, for the above mentioned reasons. As a result, they would insist on a higher rate of return on domestic currency denominated bonds to compensate them for the capital losses on maturity of those bonds. Hence the $L_{2}^{*}$ schedule would shift up to $L_{3}^{*}$ by the full extent of the further expected depreciation, $\Delta \hat{E}$.

At the same time, domestic borrowers with the same expectations of domestic

Figure 3. Interest Rates, Risk and Expected Depreciation

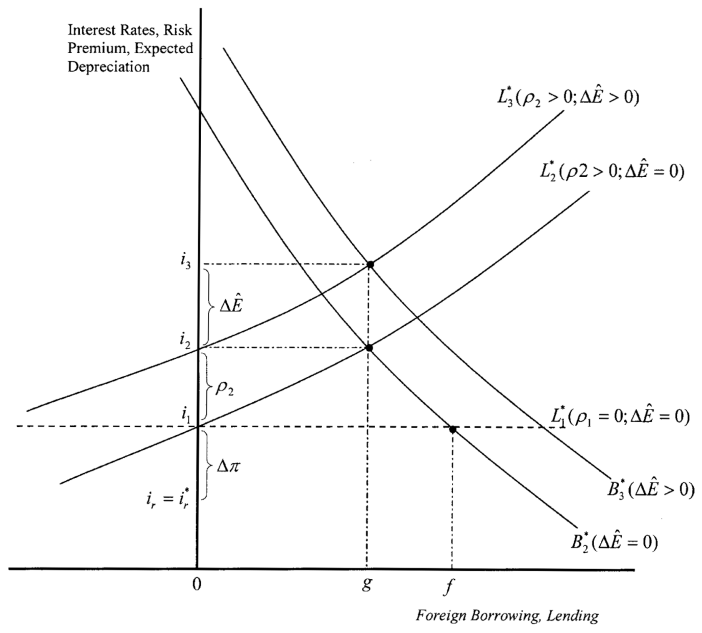


currency depreciation realise that a future weakening of the home economy's exchange rate confers a capital gain on the foreign currency acquired from foreign lenders in exchange for bonds denominated in domestic currency. This would effectively lower the cost to residents of external borrowing and hence increase the issue of home currency denominated bonds. In Figure 3, this is depicted as an outward shift of $B_{2}^{*}$ to $B_{3}^{*}$.

In sum therefore, the difference between the observed domestic interest rate and the foreign interest rate can be decomposed into its main components, the inflation gap, risk and further expected exchange rate depreciation. That is,

$$
i=i_{4}^{*}+\Delta \pi+\rho+\Delta \hat{E}
$$

\section{Conclusion}

The partial theorems of international finance that are encompassed in the more general analytical framework developed in this paper are frequently unsupported on empirical grounds for a variety of reasons. For instance, the Fisher effect and uncovered interest parity relations are weakened by complications arising from transaction costs, tax treatment and incomplete arbitrage in asset markets.

Moreover, ex ante purchasing power parity can not fully prevail if underlying cross border arbitrage opportunities in goods and services markets on which it is premised are known to be incomplete, or if the national price indices used to measure respective inflation rates are dissimilar in their coverage. In addition, the key partial relations of international finance implicitly assume that domestic and foreign borrowers and lenders form their expectations rationally and that there are no information asymmetries. This is unrealistic.

Nevertheless, this paper provides a useful way of understanding the main factors influencing international interest differentials and for systematically interpreting interest rate parity and deviations from it with reference to economywide variables. With international borrowing and lending activity as its central focus, it also reconciles traditional loanable funds analysis with other standard relationships that govern interest rate behaviour.

More specifically, it shows that the differential between a small borrower economy's domestic interest rate and the world interest rate can be graphically decomposed into the gap between domestic and world inflation, a risk premium, and further exchange rate depreciation expected by residents and foreigners alike. 
The reaction of foreign lenders was shown to be central to determining the interest risk premium paid by resident borrowers in a small open economy.

Empirical studies have shown that risk premia are extremely volatile, and according to de Grauwe (1996, p.32), no existing theory has been able to explain which factors lead to changes in the observed risk premium. To the contrary, the above approach shows why risk premium may vary considerably over time due to foreign investors perceptions about the economy's creditworthiness or noneconomic factors, such as political instability.

At the same time, changing exchange rate expectations, can also be expected to influence observed interest differentials significantly, for instance when economies' are forced to exit from pegged exchange rates and during crisis episodes. Quantifying the degree of variation in small economies interest rates from 'world' rates, along the lines of the methodology of this paper, would be a useful topic for future research.

Received 1 February 2002, Accepted 6 November 2002

\section{References}

Aliber, R.Z. (1973) “The Interest Rate Parity Theorem: A Reinterpretation”, Journal of Political Economy, 81 (6), 1451-59.

Cumby, R.E. (1988) "Is it Risk? Explaining Deviations from Uncovered Interest Parity", Journal of Monetary Economics, 22, 279-99.

Cumby, R.E. and Mishkin, F.S. (1986) "The International Linkage of Real Interest Rates: The European-US Connection”, Journal of International Money and Finance, 5, 523.

de Grauwe, P. (1996) International Money, $2^{\text {nd }}$ edition, Oxford University Press, Oxford. Dooley, M.P. and Isard, P. (1980) "Capital Controls, Political Risk and Deviations from Interest Rate Parity", Journal of Political Economy, 88, 370-84.

Dornbusch, R. (1992) "Purchasing Power Parity" in J. Eatwell, M. Milgate and P. Newman (eds), The New Palgrave Dictionary of Economics, London: Macmillan.

Dutton, M.M. (1993) "Real Interest Rate Parity: New Measures and Tests", Journal of International Money and Finance, 12, 62-77.

Fisher, I. (1930) The Theory of Interest, New York: Macmillan.

Fleming, J.M. (1962) "Domestic Financial Policy Under Fixed and Floating Exchange Rates", IMF Staff Papers, 9(3), 369-79.

Fukao, M. (1993) "International Integration of Financial Markets and the Cost of Capital", Journal of International Securities Markets, 7, 75-90.

Fujihara, R.A. and Mougoue, M. (1996) "International Linkages between Short-term Real 
Interest Rates", The Quarterly Review of Economics and Finance, 36(4), 451-73. Isard, P. (1992) "Uncovered Interest Parity", in J. Eatwell, M. Milgate and P. Newman (eds) The Palgrave Dictionary of Money and Finance, London: Macmillan.

Kneeshaw, J.T. and Van den Bergh, P. (1985) "International Interest Rate Relationships: Policy Choices and Constraints", BIS Economic Papers, 13, January.

Lewis, K.K. (1995) "International Financial Markets" in G. Grossman and K. Rogoff (eds) Handbook of International Economics, Amsterdam: North-Holland.

Mark, N.C. (1985) "Some Evidence on the International Inequality of Real Interest Rates", Journal of International Money and Finance, 4, 189-208.

Marston, R.C. (1995) International Financial Integration, New York: Cambridge University Press.

Meerschwam, D.M. (1991 ) Breaking Financial Boundaries.' Global Capital, National Deregulation and Financial Services Firms, Boston: Harvard Business School.

Mishkin, F.S. (1984) “Are Real Interest Rates Equal Across Countries? An Empirical Investigation of International Parity Conditions", Journal of Finance, 39, 1345-57.

Mundell, R.A. (1963) "Capital Mobility and Stabilisation Policy Under Fixed and Flexible Exchange Rates", Canadian Journal of Economics and Political Science, $29,475-85$.

Rogoff, K. (1996) “The Purchasing Power Parity Puzzle”, Journal of Economic Literature, 34(2), 647-68.

Roll, R. (1970) The Behaviour of Interest Rates, New York: Basic Books.

Roll, R. and Solnik, B. (1979) "On Some Parity Conditions Encountered Frequently in International Economics”, Journal of Macroeconomics, 1 (3), 267-83.

Taylor, M.P. (1995) “The Economics of Exchange Rates", Journal of Economic Literature, 33 (1), 13-47.

Throop, A.W. (1994) "International Financial Market Integration and Linkages of National Interest Rates", Federal Reserve Bank of San Francisco Economic Review, 3, 3-18.

Tsiang, S.C. (1989) "Loanable Funds" in J. Eatwell, M. Milgate and P. Newman (eds) The New Palgrave: Money, London: Macmillan, 190-94.

Van Horne, J.C. (2000) Financial Market Rates and Flows, 6th ed., New Jersey: PrenticeHall. 